\title{
The Impact of Industry on the Environment
}

\author{
Aslı Gül ÖNCEL
}

\begin{abstract}
The direct environmental aspects are basically emissions to the atmosphere, discharges into the aquatic environment, waste management, exploitation of natural resources and contamination of soil, utilization of natural resources and row material, local nuisance, transportation problem, environmental accident and effects on biological diversity. Activities, products and services of a company may cause significant environmental aspects that are beyond its control. Those are named indirect environmental aspects. In this context, the goal of our study is to show annual greenhouse gases emitted by industrial activities in the European Union countries for the period 2008-2016 and to develop recommendations for reducing environmental damage. Our approach goes to make statistical analysis and we will first examine greenhouse gas emissions by source sector and greenhouse gas emissions intensity of energy consumption. European environment agency and Eurostat data will be our main data in our statistical analysis.
\end{abstract}

Keywords-Environment, Industry, Pollution,Statistics

\section{INTRODUCTION}

The direct environmental aspects are basically emissions to the atmosphere, discharges into the aquatic environment, waste management, exploitation of natural resources and contamination of soil, utilization of natural resources and row material, local nuisance, transportation problem, environmental accident and effects on biological diversity. Activities, products and services of a company may cause significant environmental aspects that are beyond its control. Those are named indirect environmental aspects. For this reason, Industrial process need to be part of the sustainable development which means the satisfaction of present needs without compromising the ability of future generations to meet their own needs (WCED,1987).

An industry is a group of businesses that are related in terms of their main activity. In this context, industry grouping can be classified as energy-intensive manufacturing, nonenergy-intensive manufacturing, and nonmanufacturing. During this process, using only fossil resources on business create negative effects on environment but also a bigger problem in the future (Öncel A.G,Tzanakis T.2018). In this purpose, environmental corporate social responsibility has a target to minimize any damaging effects on the environment from the business processes. Corporate social responsibility is necessarily a concept whereby companies decide intentionally to commit to a cleaner environment.

Aslı Gül ÖNCEL is with Galatasaray University, Management Department, Ortaköy Istanbul Turkey.
In this context, the goal of our work is to show annual greenhouse gases emitted by industrial activities and to develop recommendations for reducing environmental damage. Our approach goes to make statistical analysis and we will first examine greenhouse gas emissions by source sector and greenhouse gas emissions intensity of energy consumption. European environment agency and Eurostat data will be our main data in our statistical analysis.

\section{INDUSTRIALISATION AND CORPORATE SOCIAL RESPONSABILITIES}

The essential origin of Greenhouse gases are mainly burning of fossil fuels, deforestation, transportation, electricity production, industry, agriculture and increase in population. Carbondioxyde (CO2), Methane (CH4), Nitrous Oxide (N2O) and Fluorinated gases are basic greenhouse gases. Carbon dioxide increase in the atmosphere through burning fossil fuels like oil, coal or natural gas, waste and also as a result of certain chemical reactions. For example, manufacture of cement has big share in chemical reactions reason. Carbondioxide is sequestered from the atmosphere via photosynthesis (EPA,2018). Methane is mostly exhaled during the extraction of coal, natural gas and oil. Some agricultural process and also corrosion of solid waste in disposal area can create methane emissions. Agricultural and some industrial process are some of the reasons of nitrous oxide emissions. Fluorinated gases are produced by industrial process. Despite the fact that they don't harm the atmospheric ozone layer however their global warming effect is 23000 times greater than carbon dioxide (European Commission, 2018)

Generally, the average citizen has developped a culture that create or tolerates environmental pollution until some major environmental event occurs. However not all citizens have the same capacity to generate pollution. Many criteria affect on each country's share of $\mathrm{CO}_{2}$ emissions. Data collected by the International Energy Agency (IEA) measure worldwide carbon dioxide emissions for year 2015. This one is composed of oil and other fuels, including industrial waste and non-renewable municipal waste, the coal, the natural gas. In first 3 ranking of 2015 total carbondioxyde emissions (MMTmillion metric tons) from fuel combustion, we see in order China (9040,74 MMT), United States (4997,50 MMT) and India (2066,01 MMT). We observe from the rest of data that principal carbon dioxide emmiting countries are the developed and major emerging economy ones. At this point, one of the opinions is that the capitalocene is a concept that takes as a starting point the idea that capitalism is the main cause of current environmental imbalances. This concept alternative to the concept of anthropocene and first time proposed in 2009 by Andreas Malm, a $\mathrm{PhD}$ student at Lund university in 
Sweden. The Capitalocene signifies capitalism as a way of organizing nature (Moore J.W. 2016) and Malm clearly precise that "Blaming all of the humanity for climate change lets capitalism off the hook" (Malm A.,2015). From that point of view, we can say that we would no longer speak only of living the era of the anthropocene, but of the capitalocene, as they are more responsible than others in the use of fossil fuels. Environmental footprint per each country appears to be one of the supporting argument of this idea for the reason that not all countries pollute the environment on same level. On this stage, for each industrialized country, corporate social responsability becomes an important key for a the sustainability of all economic activities.

"There is one and only social responsibility of business: to use its resources and engage in activities designed to increase its profits" stated Milton Friedman, a Nobel laureate (Friedman, 1970). Whereas he stated that the main responsibility for a company was to make money and increase profits, David Packard, Hewlett Packard (HP) is of the view that a company needs to do more than just to make money: The company needs to contribute to society (Young S.T., Dhanda K.K, 2013). From this second point of view, Corporate Social Responsibility (CRS) is also known by other terms, some of which are business or corporate citizenship, strategic philosophy (Werther and Chandler, 2011).

According to Wilson(200) roots of CRS go back to early Greek society. The first formal definition of formal definition of social responsibility was given by Howard R. Bowen (1953): " It refers to the obligations of businessmen to pursue those policies, to make those decisions, or to follow those lines of action which are desirable in terms of the objectives and values of our society" (Caroll, 1999).

Corporate Social Responsibility (CSR) is to take into account the expectations of various stakeholders, to identify those that the company wants or may seek to satisfy and to be publicly accountable for its actions and performance. Today, stakeholders' expectations which the company must address are: customers, employees, community, shareholders, governments, suppliers and competitors. In other words, The concept of corporate social responsibility essentially means that they decide on their own initiative to help improve society and a cleaner environment. A company is putting pressure on the environment, both direct and indirect. This pressure is created of its activity, the products it makes or the services it produces (Więcek-Janka E., Jaźwińska D.,2019). The direct environmental aspects are given as follow:

- Emissions to the atmosphere,

- Discharges into the aquatic environment;

- Waste management,

- Exploitation of natural resources and contamination of soil,

- Utilization of natural resources and row material,

- Local Nuisance,

- Transportation problem,

- Environmental accident,

- Effects on biological diversity.

Activities, products and services of a company may cause significant environmental aspects that are beyond its control. Those indirect environmental aspects are given as follow:

- Issues related to the product,

- Investments, Lending and Insurance Services,

- New markets,

- Choice and composition of the services,

- Executive decisions and planification,

- Composition of the product range,

- Outcomes and practices observed by environmental contractors, subcontractors and suppliers.

In case of all this direct and indirect environmental aspect are not taken under consideration by enterprises, we see their effects as a pollution. On this view, on the next section, we focus on the relation between pollution quantities and economic activities.

\section{POLLUTION AND ECONOMIC ACTIVITIES}

In the table 1, we show annual greenhouse gases emitted by economic activities for year 2015. Data extracted from Eurostat include agriculture, forestry and fishing; mining and quarrying; manufacturing; electricity, gas, steam and air conditioning supply; transportation and storage; other services, water supply and construction and also households.

In this paper, multiple linear regression model is used for analyzing the relationship among $\mathrm{CO}_{2}$ emissions based on the industrial consumption in EU using the time series data for the period 2008-2016. When applying multiple regression, we construct a model to explain variability in the dependant variable. In order to do this we want to include the simultaneous and individual influences of several independent variables (Newbold P.,at all, ). Regression analysis is used to predict the future on the basis of data collected from the past. The standardized beta coefficient $(\boldsymbol{\beta})$ measures the effect of each independent variable on the dependent variable to compare the effects across independent variables. In our study, $\beta$ was used to generate regression equations to retrieve the $\mathrm{CO}_{2}$ emissions over the study area using different greenhouse gas emissions by different economic activity of the $28 \mathrm{EU}$ countries.

A predictive equation for total $\mathrm{CO}_{2}$ emissions was obtained by using the terms of $[\beta$. The multiple regression equation for a response variable $\mathrm{Y}$ with monitor values $\mathrm{Y}_{1}, \mathrm{Y}_{2}, . ., \mathrm{Yn}$. Here $\mathrm{n}$ is the sample size. The equation is:

$Y_{i}=\beta_{0}+\beta_{1} X_{1 i}+\beta_{2} X_{2 i}+\cdots+\beta_{q} X_{q i}$

where $\mathrm{q}$ refers to explanatory variables $\sqrt{X_{1}}, \sqrt{X_{7}}, \ldots, \sqrt{X_{q}}$ with observed values $\sqrt{X_{1 i}}, \sqrt{X_{2, i}}, \ldots, \sqrt{X_{q i}}$ for $\mathrm{i}=1, \ldots, \mathrm{n} \quad \overline{\beta_{0}}$ is a regression equation constant, and $\beta_{0}, \beta_{1, \ldots} \beta_{n}$ are explanatory variable constants.

Multiple linear regression modelling of $\mathrm{CO}_{2}$ emissions was carried out to generate regression equation for calculating the $\mathrm{CO}_{2}$ emissions in European Union countries from 2008 to 
(thousands tonnes of $\mathrm{CO}_{2}$ equivalents)

\begin{tabular}{|c|c|c|c|c|c|c|c|c|c|}
\hline & $\begin{array}{c}\text { All } \theta \text { conomlc } \\
\text { activitles }\end{array}$ & $\begin{array}{l}\text { Agriculture, } \\
\text { forestry and } \\
\text { nlshing }\end{array}$ & $\begin{array}{l}\text { Mining and } \\
\text { quarrying }\end{array}$ & Manufacturing & $\begin{array}{c}\text { Electriclty. } \\
\text { gas, steam } \\
\text { and alr } \\
\text { conditloning } \\
\text { supply }\end{array}$ & $\begin{array}{l}\text { Transportatıo } \\
\text { n and storage }\end{array}$ & $\begin{array}{c}\text { Other } \\
\text { servlces, } \\
\text { water supply } \\
\text { and } \\
\text { construction }\end{array}$ & Households & $\begin{array}{c}\text { Economic } \\
\text { activities } \\
\text { plus } \\
\text { households }\end{array}$ \\
\hline EU-28 & 3.563 .578 & 530.948 & 79.518 & 843.475 & 1.144 .807 & 492.506 & 472.325 & 868.828 & 4.432 .406 \\
\hline Belglum & 88.086 & 12.139 & 29 & 35.306 & 17.030 & 10.396 & 13.186 & 26.625 & 114.711 \\
\hline Bulgarla & 50.508 & 3.988 & 447 & 6.543 & 31.773 & 6.005 & 1.753 & 9.804 & 60.312 \\
\hline Czech Republl & 99.161 & 8.602 & 8.157 & 18.244 & 48.039 & 6.130 & 9.990 & 13.460 & 112.621 \\
\hline Denmark & 74.662 & 12.344 & 1.883 & 5.654 & 9.664 & 38.750 & 6.367 & 8.263 & 82.925 \\
\hline Germany & 768.074 & 78.384 & 6.677 & 165.993 & 345.517 & 86.209 & 85.294 & 184.338 & 952.412 \\
\hline Estonla & 17.270 & 1.414 & 87 & 2.388 & 10.388 & 1.723 & 1.271 & 1.040 & 18.310 \\
\hline Ireland & 50.830 & 19.946 & 236 & 6.869 & 11.253 & 8.303 & 4.223 & 12.165 & 62.995 \\
\hline Greece & 74.244 & 9.102 & 399 & 13.030 & 35.621 & 6.778 & 9.315 & 15.475 & 89.719 \\
\hline Spaln & 265.266 & 48.300 & 1.076 & 79.049 & 73.703 & 35.795 & 27.342 & 68.352 & 333.619 \\
\hline France & 324.750 & 92.323 & 992 & 90.918 & 26.298 & 44.295 & 69.925 & 123.836 & 448.586 \\
\hline Croatla & 17.609 & 3.339 & 716 & 4.453 & 3.834 & 1.074 & 4.192 & 5.468 & 23.077 \\
\hline Italy & 324.436 & 38.521 & 3.650 & 94.962 & 95.168 & 47.054 & 45.081 & 103.653 & 428.090 \\
\hline Cyprus & 6.377 & 644 & 12 & 1.526 & 3.036 & 224 & 935 & 1.719 & 8.096 \\
\hline Latvla & 10.710 & 3.234 & 41 & 1.324 & 1.952 & 2.702 & 1.457 & 1.968 & 12.678 \\
\hline LIthuanla & 21.566 & 5.000 & 12 & 5.585 & 2.048 & 7.450 & 1.472 & 3.247 & 24.813 \\
\hline Luxembourg & 8.246 & 730 & 7 & 1.460 & 533 & 4.553 & 963 & 1.683 & 9.929 \\
\hline Hungary & 47.946 & 8.724 & 720 & 10.408 & 12.905 & 4.828 & 10.361 & 14.853 & 62.800 \\
\hline Malta & 3.229 & 68 & 3 & 28 & 502 & 2.383 & 244 & 221 & 3.450 \\
\hline Netherlands & 182.018 & 29.466 & 2.769 & 44.679 & 52.808 & 28.951 & 23.344 & 34.252 & 216.270 \\
\hline Austrla & 59.895 & 8.666 & 1.242 & 27.359 & 7.888 & 6.671 & 8.068 & 14.166 & 74.061 \\
\hline Poland & 337.556 & 44.213 & 21.557 & 61.299 & 160.098 & 16.858 & 33.531 & 48.295 & 385.851 \\
\hline Portugal & 59.950 & 9.232 & 259 & 17.950 & 15.759 & 6.022 & 10.728 & 8.473 & 68.423 \\
\hline Romanla & 103.472 & 19.897 & 5.362 & 23.383 & 33.713 & 7.746 & 13.370 & 15.992 & 119.464 \\
\hline slovenla & 14.272 & 1.986 & 302 & 2.192 & 4. 649 & 4.089 & 1.054 & 3.229 & 17.501 \\
\hline Slovakla & 37.632 & 3.198 & 530 & 13.920 & 9.953 & 3.373 & 6.658 & 2.880 & 40.512 \\
\hline Flniand & 50.957 & 8.053 & 397 & 14.150 & 13.770 & 9.014 & 5.573 & 6.488 & 57.445 \\
\hline Sweden & 51.355 & 9.081 & 1.511 & 14.215 & 6.540 & 12.848 & 7.160 & 9.792 & 61.147 \\
\hline UnIted KIngdor & 413.501 & 50.354 & 20.445 & 80.586 & 110.364 & 82.284 & 69.468 & 129.090 & 542.591 \\
\hline Norway & 54.774 & 6.102 & 15.662 & 11.986 & 1.760 & 16.125 & 3.138 & 5.115 & 59.889 \\
\hline Swltzerland & 32.586 & 6.945 & 60 & 7.171 & 690 & 7.811 & 9.909 & 18.732 & 51.318 \\
\hline Turkey & 393.978 & 67.891 & 2.094 & 117.778 & 133.177 & 26.792 & 46.246 & 74.168 & 468.146 \\
\hline
\end{tabular}

2016 which corresponding to a period of 9 years. Data on all economic activities which are agriculture, forestry and fishing; mining and quarrying; manufacturing; electricity, gas, steam and air conditioning supply; transportation and storage; other services, water supply and construction and also households were utilized as independent variables to generate the regression equation for $\mathrm{CO}_{2}$ emissions by multiple regression. The equation was shown as below:

$\mathrm{CO}_{2}$ emission $=\sqrt{\beta_{0}}+\sqrt{\beta_{1}}$ Agriculture, forestry and fishing $+\sqrt{\beta_{2}}$. Mining and quarrying $+\bar{\beta}_{3}$ Manufacturing $+\left[\beta_{4}\right.$ Electricity, gas, steam and air conditioning supply+ $\beta_{5}$ Transportation and storage+ $\sqrt{\beta_{6}}$ Construction+ ${ }_{\beta_{7}}$ Water supply, sewerage, waste management and remediation activities

The regression equation derived as below:

$\mathrm{CO}_{2}$ emission $=-435046160+2,85$ Agriculture, forestry and fishing $+1,72$ Mining and quarrying $+0,77$ Manufacturing $+1,10$ Electricity, gas, steam and air conditioning supply $+1,34$ Transportation and storage $+2,44$ Construction $+8,20$ Water supply; sewerage, waste management and remediation activities

From the obtained result, the predicted regression equation for $\mathrm{CO}_{2}$ emissions yielded strong $\mathrm{R}^{2}=0,9999$ with measured $\mathrm{CO}_{2}$ emissions. The high correlation confirmed that the predicted $\mathrm{CO}_{2}$ emission was accurate and efficient.

\section{CONCLUSION}

In our study, we focused on the relationship between $\mathrm{CO}_{2}$ emissions and various industrial consumption in EU using the time series data for the period 2008-2016. We constructed a multiple regression equation depending Eurostat data. We found that Water supply, sewerage, waste management and remediation activities have the highest value of 8,20 showing biggest effect on $\mathrm{CO}_{2}$ emissions. Reasons of this one need to be studied on a further study.

The results of the validation of $\mathrm{CO}_{2}$ emissions showed also a high correlation coefficient of $\mathrm{R} 2=0,9999$. This one confirm the efficiency of the model. In the context of $\mathrm{CO}_{2}$ emissions based on the industrial consumption, global corporations, governments of countries and individual citizens need to have their responsibility to protect the environment.

\section{ACKNOWLEDGMENT}

This work has been financially supported by Galatasaray University research fund grant no. 16.102.003. The author wish to acknowledge the support by Galatasaray University Research Foundation.

\section{REFERENCES}

[1] WCED, World Commission on Environment and Development. Our common future (the Brundtland report).Oxford. Oxford University Press, 1987.

[2] Tzanakis T., Öncel A.G., Legal and Statistical Framework of Climate Change from the EU and International Point of View, Athens Journal of Sciences, Vol.5, Issue.4, 2018 
[3] EPA, United States Environmental Protection. https://www.epa.gov/ghgemissions/overview-greenhouse-gases, 2018.

[4] European Commission, https://ec.europa.eu/clima/policies/f-gas_en, 2018.

[5] IEA, International Energy Agency. http://wds.iea.org/wds/pdf/Worldco2_Documentation.pdf

[6] Moore J.W. Anthropocene or Capitalocene?: Nature, History, and the Crisis of Capitalism (Kairos), ISBN-10: 1629631485, PM Press, 2016.

[7] Malm A., The Anthropocene Myth. https://www.jacobinmag.com/2015/03/anthropocene-capitalismclimate-change, 2015.

[8] Milton Friedman, The Social Responsibility of Business is to Increase its Profits, The New York Times Magazine, 13 Septembre 1970.

[9] Young S.T., Dhanda K.K, Sustainability: Essentials for Business.Sage Publications, 2013. https://doi.org/10.4135/9781544308432

[10] David Chandler, William B. Werther Jr. Strategic Corporate Social Responsibility: Stakeholders, Globalization, and Sustainable Value Creation, Sage publications, 2014.

[11] Wilson, Mel. Corporate sustainability: What is it and where does it come from? Ivey Business Journal, issue of Ivey Business Journal 3, March/April 2003

[12] Howard Rothmann Bowen, Social responsibilities of the businessman, Harper, 1953

[13] Caroll, Business \& Society 38(3):268-295, Corporate social responsibility: Evolution of a definitional construct, 1999.

[14] Więcek-Janka E., Jaźwińska D., Corporate Social Responsibility and EMAS - Guidelines for Sustainable Development, Researchgate publication, DOI: 10.1007/978-3-642-33851-9_10, January 2019.

[15] http://ec.europa.eu/environment/emas/join_emas/what_if_i_am_an_sme en.htm

[16] Paul Newbold, William L. Carlson and Betty Thorne, Statistics for Business and Economics, sixth edition, Pearson Prentice Hall, 2007

[17] Eurostat, https://ec.europa.eu/eurostat/data/database

[18] European environment agency https://www.eea.europa 